\title{
Chagasic patients are able to respond against a viral antigen from influenza virus
}

\author{
Paola Lasso ${ }^{1}$, Diana Mesa ${ }^{1}$, Natalia Bolaños ${ }^{2}$, Adriana Cuéllar ${ }^{3}$, Fanny Guzmán ${ }^{4}$, Zulma Cucunuba ${ }^{5}$, \\ Fernando Rosas ${ }^{6}$, Víctor Velasco ${ }^{6}$, Maria C Thomas ${ }^{7}$, Manuel Carlos Lópezz, John Mario González ${ }^{7}$ \\ and Concepción Judith Puerta ${ }^{1,8^{*}}$
}

\begin{abstract}
Background: Trypanosoma cruzi, the etiological agent of Chagas' disease, is an obligate intracellular parasite which induces a $\mathrm{CD} 8^{+} \mathrm{T}$ cell immune response with secretion of cytokines and release of cytotoxic granules. Although an immune-suppressive effect of $T$. cruzi on the acute phase of the disease has been described, little is known about the capacity of $\mathrm{CD}^{+} \mathrm{T}$ cell from chronic chagasic patients to respond to a non-T. cruzi microbial antigen.

Methods: In the present paper, the frequency, phenotype and the functional activity of the $\mathrm{CD} 8^{+} \mathrm{T}$ cells specific from Flu-MP*, an influenza virus epitope, were determined in 13 chagasic patients and 5 healthy donors.

Results: The results show that Flu-MP* peptide specific $C D 8^{+} T$ cells were found with similar frequencies in both groups. In addition, Flu-MP* specific $\mathrm{CD}^{+} \mathrm{T}$ cells were distributed in the early or intermediate/late differentiation stages without showing enrichment of a specific sub-population. The mentioned Flu-MP* specific CD8 ${ }^{+} \mathrm{T}$ cells from chagasic patients were predominately $T_{E M}$ (CCR7- CD62L-), producing IL-2, IFNY, CD107a/b and perforin, and did not present significant differences when compared with those from healthy donors.
\end{abstract}

Conclusions: Our results support the hypothesis that there is no $\mathrm{CD}^{+} \mathrm{T}$ cell nonspecific immune-suppression during chronic Chagas disease infection. Nonetheless, other viral antigens must be studied in order to confirm our findings.

Keywords: CD8 ${ }^{+}$T cells, Chagas disease, Non-T. cruzi microbial antigen, Nonspecific immune-suppression

\section{Background}

Chagas' disease, caused by the hemoflagellate parasite Trypanosoma cruzi, has a widespread distribution in Central and South America. Approximately 10 million people are infected along 21 endemic countries of Latin-America [1]. However, due to increasing migration to North America and Europe, the disease has been expanded beyond its original borders [2,3]. Infection with $T$. cruzi, results in a generally asymptomatic disease due to the fact that most of the infected individuals remains in an indeterminate chronic phase. After the acute phase, the disease becomes clinically evident in $30-40 \%$ of them with cardiac or digestive manifestations (symptomatic chronic phase) [4-7].

\footnotetext{
* Correspondence: cpuerta@javeriana.edu.co

'Laboratorio de Parasitología Molecular, Pontificia Universidad Javeriana, Carrera 7 No. 43 - 82, Bogotá, Colombia

${ }^{8}$ Departamento de Microbiología, Facultad de Ciencias, Laboratorio de Parasitología Molecular, Pontificia Universidad Javeriana, Bogotá, Colombia Full list of author information is available at the end of the article
}

Trypanosoma cruzi is an obligate intracellular parasite which invades and replicates into mammalian cells. As other intracellular infectious agents, T. cruzi induces a $\mathrm{CD}^{+} \mathrm{T}$ cell immune response with secretion of cytokines and release of cytotoxic granules $[8,9]$. The role of $\mathrm{CD} 8^{+} \mathrm{T}$ cells is crucial for controlling the T. cruzi infection. Indeed, during the acute infection, depleted $\mathrm{CD}^{+}{ }^{+} \mathrm{T}$ cells mice showed increased parasite burden in their hearts, moderate decrease in the inflammation and higher mortality compared with wild type infected animals [10]. Nonetheless, in chronic infection, there are several experimental data supporting that the suboptimal generation of functional specific effector $\mathrm{CD}^{+} \mathrm{T}$ cells leads to the lack of infection control and parasite persistence in the tissues $[11,12]$. Thus, the presence of late-differentiated $\mathrm{CD}^{+} \mathrm{T}$ cells exhibiting signs of senescence that are incapable of maintaining effector functions [11-13], and the diversity of T. cruzi antigens that can enter MHC class I processing 
pathway should be responsible of the absence of a potent and antigen focused cellular immune response [8,14]. Due to the parasite's genetic complexity and a high degree of polymorphism among strains, only a few human $\mathrm{CD}^{+} \mathrm{T}$ cell parasite-specific epitopes capable of inducing specific $\mathrm{CD}^{+} \mathrm{T}$ cell responses have been described [14-21]. Furthermore, even less is known about the capacity of chagasic patients to respond to non-chagasic microbial antigens.

A T. cruzi-induced nonspecific immune-suppression during the acute phase of the disease has been reported by several authors, showing the immunosuppressive effect on dendritic cells, macrophages, splenic T cells, and LTs [2225]. Nonetheless, experimental infection in mice indicated that there is no general immunosuppressive effect of $T$. cruzi on $\mathrm{CD}^{+} \mathrm{T}$ cell priming [26]. No data of $\mathrm{CD}^{+} \mathrm{T}$ cell immune-suppression have been reported with another derived-microbial epitopes in humans infected with T. cruzi.

The aim of the present work was to determine whether or not there is a nonspecific immune-suppression in chronic chagasic patients. Consequently, we investigated the $\mathrm{CD}^{+} \mathrm{T}$ cells response against a representative viral antigen. Thus, we examined the frequency, phenotype and the functional activity of the influenza virus specific $\mathrm{CD}^{+}$ T cells in chagasic patients and healthy donors. We selected an epitope from the viral matrix protein because the majority of individuals throughout their life have been exposed to the influenza virus and have had at least one infection.

\section{Results}

\section{Population HLA-A2 subtyping}

In this work we assessed whether the $\mathrm{CD} 8^{+} \mathrm{T}$ cells from $T$. cruzi infected patients are able to respond to non- $T$. cruzi microbial antigens such as a well described epitope from influenza virus derived from the matrix protein. Specifically, it was studied whether the frequency, phenotype and functional capacity of Flu-specific $\mathrm{CD}^{+} \mathrm{T}$ cells are modified in chronic chagasic patients with respect to healthy donors used as control. The Flu-MP* peptide, which is an HLA-A*0201 restricted epitope was used as non-T cruzi epitope since HLA-A*0201 is the most prevalent human class I allele [27]. Consequently, subjects were HLA-A2 typed by flow cytometry and subtyped for HLA$A * 0201$ by PCR. It was found that 13 out of 50 chagasic patients (26\%) were HLA-A2 ${ }^{+}$; from whom all were HLA$\mathrm{A}^{*} 0201^{+}$, classified as six chronic patients in indeterminate phase or A stage (normal electrocardiography ECG, and no major findings arising during clinical examination) and seven symptomatic chagasic patients having different disease severity levels as follows: 2 B (abnormal ECG results), 3 C (abnormal ECG results, decreased left ventricular ejection fraction, LVEF, and cardiac enlargement) and $2 \mathrm{D}$ (abnormal ECG results, cardiac enlargement, decreased LEFV, and clinical signs of heart failure). Analysis of the twelve healthy donors showed that five of them (41.7\%) were HLA-A2 ${ }^{+}$, and HLA-A*0201 ${ }^{+}$.

\section{Frequency of MP-Flu* specific CD8 ${ }^{+}$T cells}

Tetramer consisting of HLA-A*0201/Flu-MP* peptide was used to evaluate the frequency of Flu-MP* specific $\mathrm{CD}^{+} \mathrm{T}$ cells in the thirteen HLA-A*0201 ${ }^{+}$chagasic patients and five HLA-A*0201 ${ }^{+}$healthy donors. Flu-MP* peptide specific cells were found in all chagasic patients, showing a range of frequency of $0.12 \%$ to $0.36 \%$ (mean $0.21 \%$, SD = 0.07). Likewise, in the group of healthy donors all individuals had Flu-MP* peptide specific cells with a frequency range of $0.12 \%$ to $0.29 \%$ (mean $0.17 \%, \mathrm{SD}=0.07$ ). There was no difference when all the groups of patients were compared based on their clinical status (indeterminate and cardiac chronic patients) or when chagasic patients were compared with healthy donors $(\mathrm{P}>0.05)$ (Figure 1$)$.

\section{Phenotypic characterization of Flu-MP* specific-CD8 ${ }^{+} \mathrm{T}$ cells}

Several studies showed the importance of memory $\mathrm{CD}^{+}$ $\mathrm{T}$ cells in controlling viral infections in mice and human models [28]. Consequently, the phenotype of the Flu-MP*
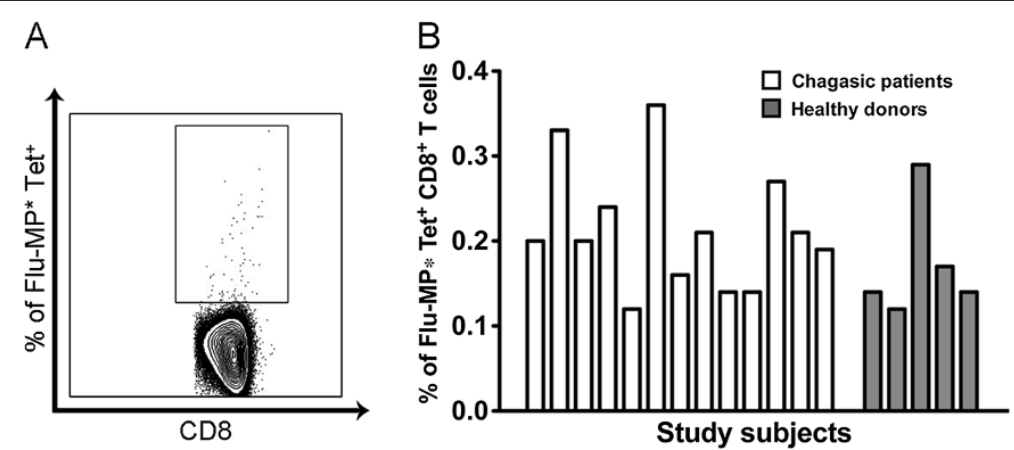

Figure 1 Frequency of $\mathrm{CD}^{+} \mathrm{T}$ cells specific for Flu-MP* peptide determined by tetramer staining. (A) Representative flow cytometry dot plot from one $\mathrm{HLA}-\mathrm{A}^{*} 0201^{+}$chagasic patient. (B) Frequency of HLA-A*0201+ chagasic patients (white bars) and $\mathrm{HLA}-\mathrm{A}^{*} 0201^{+}$healthy donors (grey bars). There were no statistically significant differences between healthy donors and chagasic patients $P=0.21$. 

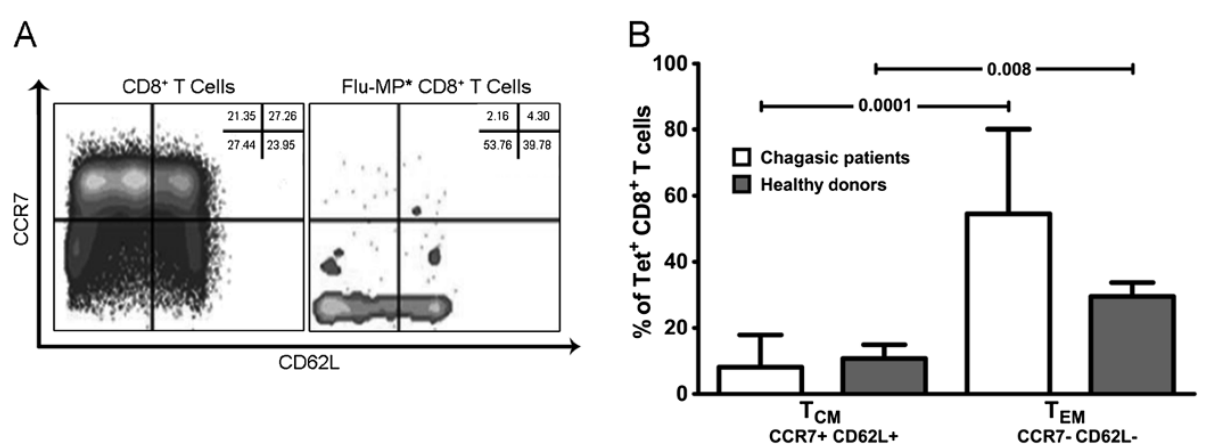

Figure 2 Expression of CCR7 and CD62L in Flu-MP* peptide-specific CD8 ${ }^{+}$T cells. (A) Phenotypic characterization by flow cytometry in one representative chagasic patient. (B) Significant differences were observed between central memory (double positive cells) $T_{\text {cells }}\left(T_{C M}\right)$ and effector memory (double negative cells) T cells $\left(T_{E M}\right)(P<0.008)$ from chagasic patients (white bars) or healthy donors (grey bars). No differences were found when the frequencies of $\mathrm{T}_{\mathrm{CM}}$ and $\mathrm{T}_{\mathrm{EM}} \mathrm{CD} 8^{+} \mathrm{T}$ cells were compared between chagasic patients and healthy donors.

specific CD ${ }^{+}$T cells from HLA-A*0201 ${ }^{+}$infected patients and healthy donors was determined by analyzing the expression of CCR7, CD62L, CD27 and CD28. It was found that the Flu-MP* peptide-specific $\mathrm{CD}^{+} \mathrm{T}$ cells were predominately $\mathrm{T}_{\mathrm{EM}}$ (CCR7- CD62L-) in both indeterminate and cardiac chronic chagasic patients without statistically differences $(P=0.206)$. Moreover, no differences were found when the expression in chagasic patients and healthy donors were compared $(\mathrm{P}=0.055)$. However, significant differences were observed when the percentages of Flu-MP* peptide specific $\mathrm{T}_{\mathrm{CM}}$ and $\mathrm{T}_{\mathrm{EM}}$ cells from chagasic patients or healthy donors $(\mathrm{P}=0.0001$, and $\mathrm{P}=0.008$, respectively) were compared (Figure 2). As the $\mathrm{CD}^{+} \mathrm{T}$ cell differentiation degree, based on CD28, and CD27 expression, well correlates with their functional capacity [29], the Flu-specific $\mathrm{CD}^{+} \mathrm{T}$ cell stage of differentiation was compared among donors. It was found that Flu-MP* peptide-specific $\mathrm{CD}^{+} \mathrm{T}$ cells are equally distributed in the early and intermediate/late differentiation stages without showing any enrichment of a specific population. There were no statistically significant differences between chagasic patients and healthy donors (Figure 3).

\section{Functional characterization of Flu-MP* specific-CD8 ${ }^{+} \mathrm{T}$ cells}

To assess the functional characteristics of Flu-MP* specific $\mathrm{CD}^{+} \mathrm{T}$ cells, the IL- 2 and IFN $\gamma$ cytokine production and cytotoxic capacity, measured by the perforin secretion and $\mathrm{CD} 107 \mathrm{a} / \mathrm{b}$ surface expression, were evaluated in PBMC from ten chagasic patients and 5 healthy donors. For perforin analysis, it was observed that Flu-MP* peptide specific $\mathrm{CD}^{+} \mathrm{T}$ cells from $T$. cruzi-infected volunteers had similar percentage of expression, ranging from $17.56 \%$ to $77.78 \%$ (mean $41.4 \%, \mathrm{SD}=20.60 \%$ ), than that from the healthy group of donors which ranged from $30.3 \%$ to $61.5 \%$ (mean $50.62 \%, \mathrm{SD}=12.05 \%$ ). The surface expression of CD107a/b was detected in Flu-MP* peptide specific $\mathrm{CD}^{+} \mathrm{T}$ cells from both chagasic patients and healthy donors, with percentages ranging from 0.52 to $5.71 \%$ (mean $2.50 \%, \mathrm{SD}=2.05 \%$ ) and $0.47 \%$ to $24.2 \%$
A

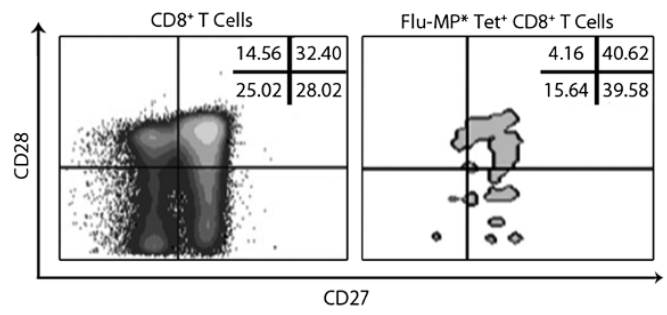

B

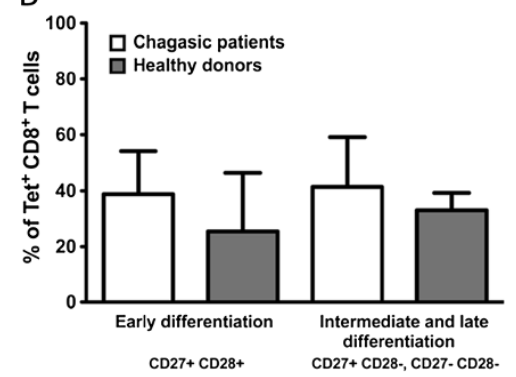

Figure 3 Expression of CD27 and CD28 in Flu-MP* peptide-specific CD8 ${ }^{+}$T cells. (A) Flow cytometry dot plot of CD27 and CD28 expression in one representative chagasic patient. (B) There were no differences between the early differentiation phenotype (CD27+ CD28+) and the intermediate/late differentiation stage (CD27+ CD28-, CD27- CD28-) in CD8 ${ }^{+} T$ cells ( $\left.P>0.151\right)$. There were no significant differences between the chagasic patients (white bars) and healthy donors (grey bars) when comparing the early phenotype $(P=0.139)$ with intermediate/late differentiation stage $(P=0.430)$. 
(mean $12.01 \%, \mathrm{SD}=8.57 \%$ ), respectively. Furthermore, no differences in percentage, mean fluorescence intensity (MFI) or integrated mean fluorescence intensity (iMFI) in CD107a/b between chagasic patients and healthy donors were observed (Figure 4A, 4B). IL-2 was detected in eight out of ten infected patients with a range from $0.21 \%$ to $7.37 \%$ (mean $1.87 \%, \mathrm{SD}=2.6 \%$ ) and in all studied healthy donors with a range from $0.56 \%$ to $1.57 \%$ (mean $1.09 \%$, $\mathrm{SD}=0.42 \%)$. IFN $\gamma$ production was detected in Flu-MP* specific $\mathrm{CD}^{+} \mathrm{T}$ cells with a range from $0.51 \%$ to $3.42 \%$ (mean $1.61 \%, \mathrm{SD}=1.13 \%$ ) in nine out of ten chagasic patients and in all healthy donors with a frequency range of $1.33 \%$ to $3.07 \%$ (mean $2.06 \%$, SD $=0.74 \%$ ). Consequently, no differences in cytokines production were observed in terms of percentage, MFI or $i$ MFI when both groups were compared (Figure 4C, 4D).

\section{Discussion}

Chagas disease is a persistent parasitic infection that does not induce sterilizing immunity. The generation of memory $\mathrm{T}$ cell response depends on the environmental conditions at the initial antigenic priming [30]. Indeed, the $\mathrm{T}$ cell responses may be influenced by previous antigen encounters, a phenomenon known as "original antigenc sin" [31]. Thus, the goal of this study was to determine whether chagasic patients are able to respond against a non- $T$. cruzi microbial antigen such as the matrix peptide derived from influenza virus. Exposure to influenza virus
A

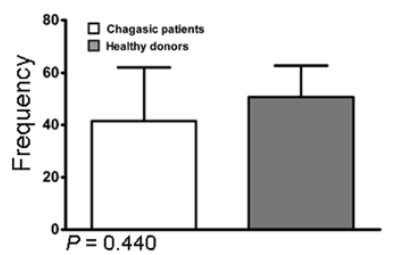

B

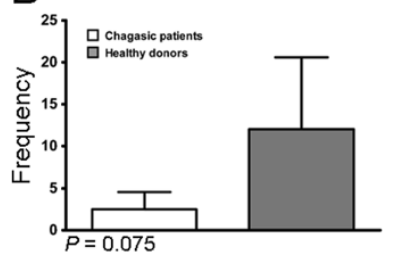

C

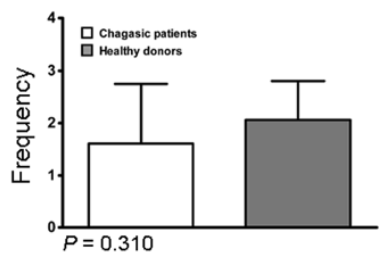

D

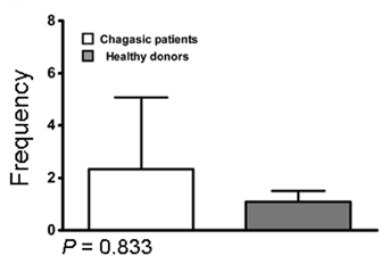

Perforin
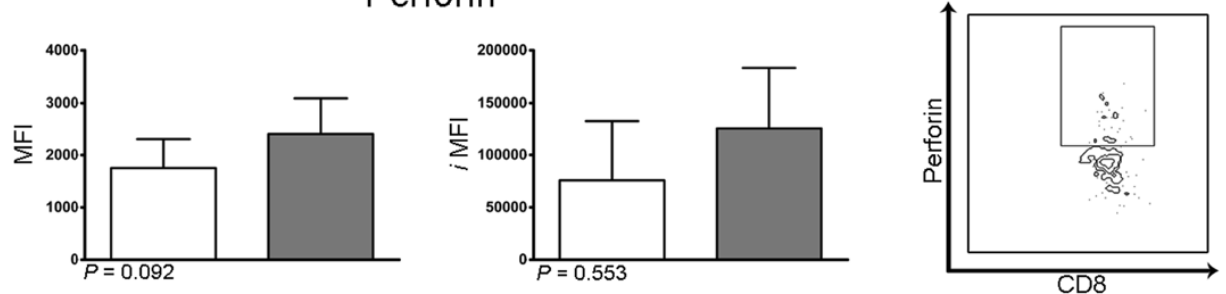

\section{CD107a/b}
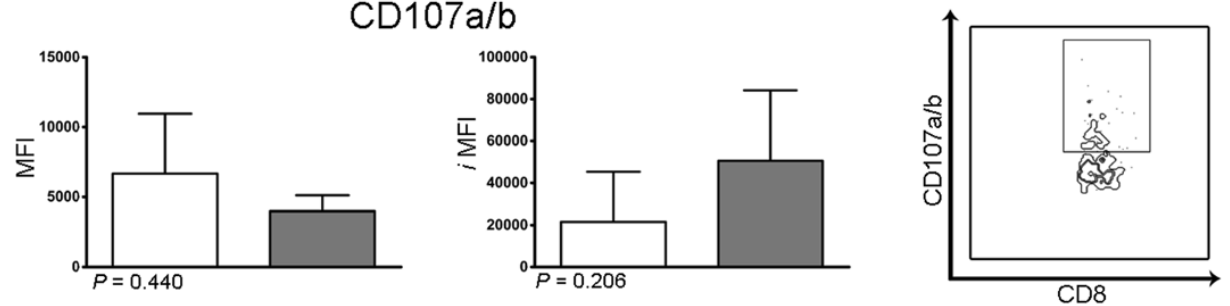

IFN $\gamma$
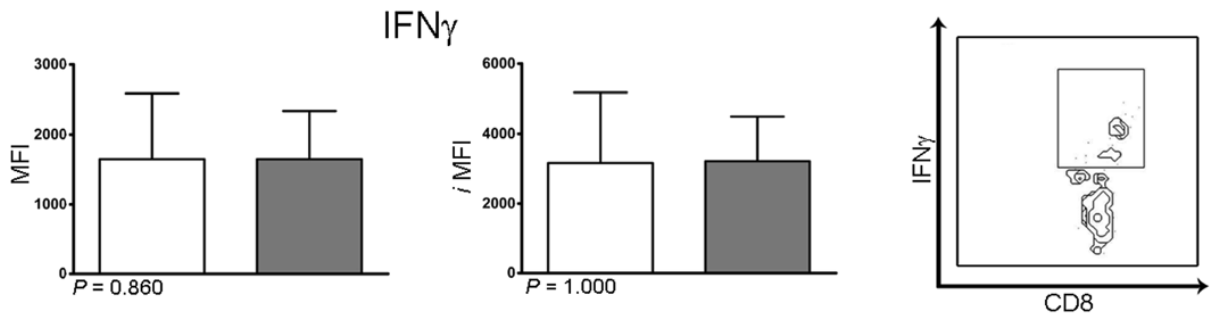

IL-2
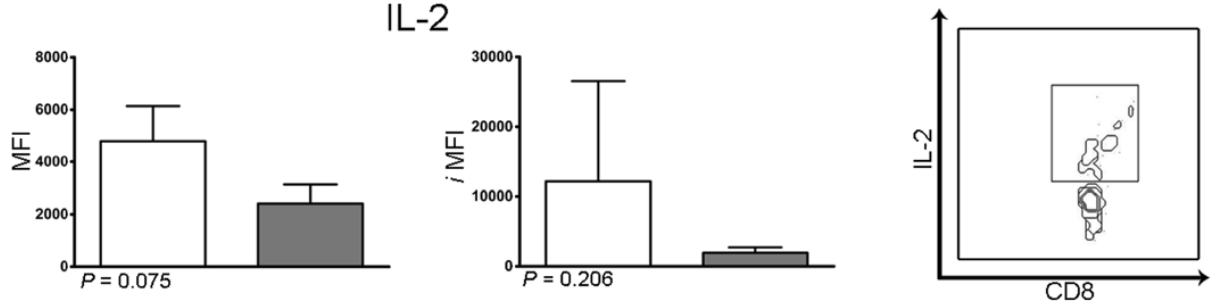

Figure 4 Functional characterization of $\mathrm{CD}^{+} \mathrm{T}$ cells specific for Flu-MP* peptide determinated by flow cytometry. Frequency, mean fluorescence intensity (MFI) and integrated mean fluorescence intensity (iMFI) of the perforin (A), CD107a/b (B), IFNy (C) and IL-2 (D) expression in CD8 ${ }^{+} \mathrm{T}$ cells specific for Flu-MP* peptide in chagasic patients (white bars) and healthy donors (grey bars). A representative dot plot of the expression of each studied molecule from one $\mathrm{HLA}-\mathrm{A}^{*} 0201^{+}$chagasic patient is shown on the right side. 
is widely spread therefore most individuals develop a serotype-dependent sterilizing immunity.

At first, frequency of Flu-MP* peptide-specific $\mathrm{CD}^{+} \mathrm{T}$ cells from chronic chagasic patients and healthy donors was studied. Noticeably, no differences were found between these two groups. Moreover, the average frequency values were similar to those previously reported for the influenza-M1 $1_{58-66}$ (GILGFVFTL) specific $\mathrm{CD}^{+} \mathrm{T}$ cells $(0.28 \%$ to $0.73 \%)$ from healthy donors [32]. A similar FluMP tetramer positive cell frequency $(0.11 \%$ to $0.56 \%)$ was reported in six HLA-A*0201+ healthy donors [33]. Likewise, in a previous study we reported the existence of Flu$\mathrm{MP}^{*}$-specific $\mathrm{CD}^{+} \mathrm{T}$ cells with frequencies up to $0.36 \%$ in 16 out of 19 HLA-A2+ chagasic patients and frequencies up to $0.25 \%$ in 10 out of 12 healthy donors without statistically significant difference when non-chagasic and $T$. cruzi infected individuals were compared $(\mathrm{P}>0.05)$ [34].

Memory $\mathrm{T}$ cells consist in central $\left(\mathrm{T}_{\mathrm{CM}}\right)$ and effector $\left(\mathrm{T}_{\mathrm{EM}}\right)$ memory cells $[28,30,35]$. While human $\mathrm{T}_{\mathrm{CM}}$ express CCR7 and CD62L, molecules involved in cellular homing to lymphoid tissue, human $\mathrm{T}_{\mathrm{EM}}$ have lost the expression of CCR7 and CD62L and preferentially migrate to nonimmune tissues [28]. In this study, Flu-MP* peptidespecific $\mathrm{CD}^{+} \mathrm{T}$ cells were predominately $\mathrm{T}_{\mathrm{EM}}$ cells, in both healthy donors and chagasic patients. Results that are in agreement with reports of Hoji et al., showing that Flu-specific $\mathrm{T}$ cells from healthy donors had a lower proportion of CCR7 expression on Flu-specific T cells and a moderate expression of CD62L with a phenotype that corresponds to effector memory $\mathrm{CD}^{+}{ }^{+} \mathrm{T}$ cells [33]. Expression of $\mathrm{CD} 27$ and $\mathrm{CD} 28$ are useful in distinguishing $\mathrm{CD} 8^{+}$ $T$ cell differentiation stages: early (CD27+ CD28+), intermediate (CD27+ CD28-) and late differentiation (CD27CD28-) [28]. In our study, in the influenza-specific $\mathrm{CD} 8^{+}$ $\mathrm{T}$ cells there was not a predominant population based on CD27 and CD28 expression. During chronic viral infection, and depending on the infecting virus, there is a certain predominance of a cell stage of differentiation [29]. Nonetheless, we could not find any report in the literature showing the expression of these markers in influenzaspecific $\mathrm{CD}^{+} \mathrm{T}$ cells to be compared with our results.

$\mathrm{CD}^{+} \mathrm{T}_{\mathrm{EM}}$ cells have cytotoxic granules and produce cytokines within hours after antigenic stimulation. MP$\mathrm{Flu}^{*}$ peptide-specific $\mathrm{CD}^{+} \mathrm{T}$ cells expressed surface $\mathrm{CD} 107 \mathrm{a} / \mathrm{b}$ and were able to secrete IL-2, IFN $\gamma$ and storage perforin. Interestingly, in both infected patients and healthy donors, the expression of IL-2, IFNY and perforin by Flu-MP* peptide-specific $\mathrm{CD}^{+} \mathrm{T}$ cells was similar in magnitude (percentage of expressing cells), quality (MFI) or both (iMFI), indicating that these populations are equally functional upon Flu-MP* peptide recognition.

In agreement with results presented here, a study of congenital Chagas disease performed in newborns congenitally infected with $T$. cruzi, showed that the infection did not interfere with responses to Bacillus Calmette Guerin (BCG), hepatitis B, diphtheria, and tetanus vaccines during the neonatal period [36].

\section{Conclusion}

Our results support the hypothesis that there is no $\mathrm{CD} 8^{+}$ $\mathrm{T}$ cell nonspecific immune-suppression during chronic Chagas disease infection. Nonetheless, other viral antigens must be studied in order to confirm our findings.

\section{Methods \\ Subjects}

All individuals enrolled in the study were volunteers who signed the informed consent form and were clinically evaluated at Fundación Abood Clínica Shaio and the Instituto Nacional de Salud (Bogotá, Colombia). Fifty Chagas disease patients with positive results in both immunofluorescence assays (IFI) and enzyme-linked immunosorbent assays (ELISA) were evaluated. Patients were classified according to the classification of the Incorporating American College of Cardiology and the American Heart Association Staging [37,38], as follows: twenty-one chronic chagasic patients at indeterminate phase of the disease with normal ECG and no major findings arising during clinical examination (group A), and twenty nine cardiac chronic chagasic patients with abnormal ECG, having different disease severity levels (groups B, C and D). The group of healthy donors consisted of twelve $T$. cruzi seronegative individuals residing in non-endemic areas with normal ECG and no major clinical findings during clinical examination. Approximately a total of $20 \mathrm{~mL}$ of blood was obtained from all individuals by venipuncture in heparinized tubes to separate peripheral blood mononuclear cells (PBMCs), EDTA tubes for DNA extraction and tubes without anticoagulant for serological tests (Vacutainer; Beckton-Dickinson, San José, CA, USA). This study was approved by the Research and Ethics Committees from the Facultad de Ciencias, Pontificia Universidad Javeriana and Fundación Abood Clínica Shaio.

\section{Flu-MP* modified peptide}

An HLA-A*0201 restricted peptide derived from the influenza virus matrix protein $_{58-66}$ with a modification in the seventh position was used (GILGFVTTL) and referred as Flu-MP* [19,34,39]. Peptide was synthesized using 9fluorenylmethiloxycarbonyl (Fmoc) chemistry with a 0.64 substituted rink amide resin and Fmoc amino acids [40]. The peptides were cleaved by treatment with trifluoroacetic acid (TFA)/triisopropylsilan (TIS)/H2O (95/5/5) for $1 \mathrm{~h}$, then precipitated with cold diethyl ether and purified by reverse phase high performance liquid chromatography (HPLC). The molar mass of the peptides was determined by MALDI-TOF mass spectrometry. The lyophilized 
peptide was reconstituted in dimethyl sulfoxide (DMSO) and stored at $-20^{\circ} \mathrm{C}$.

\section{HLA-A2 typing by flow cytometry}

Individual HLA-A2 typing was performed by incubating $50 \mu \mathrm{L}$ of peripheral blood with HLA-A2-specific antibody BB7.2-FITC (Becton Dickinson, Mountain View, California, USA) for $20 \mathrm{~min}$ at $4^{\circ} \mathrm{C}$, followed by additional 15 min incubation. After adding red blood cells lysis buffer and 1X PBS washing [41], data were acquired and analyzed using a FACSCanto II flow cytometer and analyzed using FACSDiva (BD Biosciences) software.

\section{HLA-A*0201 subtyping by PCR}

A total of 50-150 ng genomic DNA was extracted from peripheral blood using a GFX genomic blood DNA purification kit (Amersham Biosciences, Piscataway, NJ, USA), and amplified using the 296 (5'-GTGGATAGAGCAGGAGGCT-3'), and 302 (5'-CCAAGAGCGCAGGTCCTCT-3') primers. The PCR reaction was carried out according to Lasso et al. 2010 in a Stomacher 3500 Thermal Cycler, PTC 100 (MJ Research, Watertown, MA, USA) [34]. The expected 489 bp amplified product was separated on ethidium bromide stained $1.5 \%$ agarose gels [42].

\section{$T$ cell frequency determination}

HLA-A2 PE-labeled tetramer loaded with the Flu-MP* peptide, was synthesized by the National Institute of Health (NIH) Tetramer Facility (Atlanta, USA). Peripheral blood mononuclear cells (PBMCs) of all individuals were prepared using Ficoll-Hypaque density gradient (Sigma, St. Louis, MO), adjusted to $1 \times 10^{6}$ cells per tube and stained with tetramer at $0,5 \mu \mathrm{g} / \mathrm{mL}$, anti-CD3-PerCP and anti-CD8-FITC (BD Biosciences, San José, CA, USA) for $20 \mathrm{~min}$ in the dark at room temperature [34]. After washing with staining buffer ( $1 \%$ fetal bovine serum in PBS $1 \mathrm{X})$, cells were resuspended with $500 \mu \mathrm{L}$ of PBS $1 \mathrm{X}$. Data were acquired in a FACSCanto II flow cytometer and analyzed using FACSDiva software (BD, Bioscience, San José, CA, USA). Frequencies of Flu-specific $\mathrm{CD}^{+} \mathrm{T}$ cells are the result of the frequency obtained minus the background of unlabeled cells with the tetramer.

\section{T cell phenotyping and function}

PBMCs were adjusted to $2 \times 10^{6}$ cells per tube and labeled with tetramers at $0.5 \mu \mathrm{g} / \mathrm{mL}$, anti-CD3-PerCP, antiCD8-APC-Cy7, anti-CCR7-PECy7, anti-CD62L-APC for $20 \mathrm{~min}$ in the dark at room temperature (all antibodies were purchased from BD Biosciences and BD Pharmingen, San Diego, CA, USA). After washing with $2 \mathrm{~mL}$ staining buffer ( $1 \%$ fetal bovine serum in PBS $1 \mathrm{X}$ ), cells were fixed with $0.5 \%$ formaldehyde in PBS $1 \mathrm{X}$. To determine intracellular perforin expression, after surface antigens staining, $\mathrm{CD} 8^{+} \mathrm{T}$ cells were permeabilized with Cytofix/Cytoperm (BD Pharmingen), washed twice with Perm/Wash ${ }^{\mathrm{TM}}$ (BD Pharmingen) and stained with antiperforin-FITC or mouse IgG2b $\mathrm{k}$ isotype control for $30 \mathrm{~min}$ at $4^{\circ} \mathrm{C}$. Intracellular cytokines were detected in PBMCs stimulated with Flu-MP* peptide in the presence of CD28 $(1 \mu \mathrm{g} / \mathrm{mL})$, and CD $49 \mathrm{~d}(1 \mu \mathrm{g} / \mathrm{mL})$ for $12 \mathrm{~h}$ at $37^{\circ} \mathrm{C}$. The last $9 \mathrm{~h}$ of culture were performed in the presence of brefeldin A $(10 \mu \mathrm{g} / \mathrm{mL})$ (BD Pharmingen). Then, cells were permeabilized and stained with anti-IFNy-PECy7 and antiIL-2-APC for $30 \mathrm{~min}$ at $4^{\circ} \mathrm{C}$. To evaluate the cytotoxic activity, anti-CD107a and anti-CD107b-FITC were added to the PBMCs prior to stimulation. In each experiment, nonstimulated cells were used as negative control and Staphylococcal enterotoxin B $(3.7 \mu \mathrm{g} / \mathrm{mL})$ as positive control. Data were acquired in a FACSCanto II flow cytometer and analyzed using FACSDiva (BD Biosciences) software. Results were expressed as percentage, mean fluorescence intensity (MFI) and integrated mean fluorescence intensity (iMFI) obtained multiplying the frequency by the MFI. The latter was obtained multiplying the frequency by the MFI of tetramer positive $\mathrm{CD}^{+} \mathrm{T}$ cells [43].

\section{Statistical methods}

Differences among groups were assessed by Mann Whitney test. GraphPad InStat 3.0 statistics software was used for analyses. $\mathrm{P}<0.05$ was considered statistically significant.

Competing interests

The authors declare that they have no competing interests.

\section{Authors' contribution}

$\mathrm{PL}$ performed the experiments, participated in the data analysis and wrote the manuscript. DM and NB performed the experiments and participated in the data analysis. AC and JMG participated in the designed the study, analyzed the data and collaborated writing the manuscript. ZC, W and FR recruited and assessed the patients and collected the clinical information. $\mathrm{MCT}, \mathrm{MCL}$ and FG participated in the data analysis and collaborated writing the manuscript. CPB conceived and designed the study, obtained financial support, analyzed the data and wrote the manuscript. All authors participated in revising the manuscript. All authors have read and approved the final manuscript.

\section{Acknowledgements}

The HLA-A2/Flu-MP* tetramers were generated and kindly provided by the $\mathrm{NIH}$ Tetramer Facility. This work was supported by Colciencias Research project No. 1203-333-18692, and COLCIENCIAS and CONICYT COLCIENCIAS and CONICYT 2008-151, Research Exchange Program. JMG was supported by an associate professor grant form Vicerrectoria Académica, Universidad de los Andes, Colombia. MC López and MC Thomas were supported by Grants P08-CVI-04037 from PAI (Junta de Andalucía), BFU2010-1670 from Plan Nacional I + D + i (MICINN) and RD06/0021/0014 from ISCIII-RETIC (MICINN Spain and FEDER)

\section{Author details}

${ }^{1}$ Laboratorio de Parasitología Molecular, Pontificia Universidad Javeriana Carrera 7 No. 43 - 82, Bogotá, Colombia. Grupo de Ciencias Básicas Médicas, Facultad de Medicina, Universidad de los Andes, Carrera 1 No. 18A - 10, Bogotá, Colombia. ${ }^{3}$ Grupo de Inmunobiología y Biología Celular, Pontificia Universidad Javeriana, Carrera 7 No. 43 - 82, Bogotá, Colombia. ${ }^{4}$ Núcleo de Biotecnología Curauma, Pontificia Universidad Católica de Valparaíso, Avenida Universidad 330, Valparaíso, Chile. ${ }^{5}$ Grupo de Parasitología, Instituto Nacional de Salud, Avenida Calle 26 No. 51 - 20, Bogotá, Colombia. 
${ }^{6}$ Fundación Clínica Abood Shaio, Diag. 115A No. 70C - 75, Bogotá, Colombia. ${ }^{7}$ Instituto de Parasitología y Biomedicina López Neyra, Consejo Superior de Investigaciones Científicas (IPBLN-CSIC), Parque Tecnológico de Ciencias de la Salud, Avda. del Conocimiento, s/n.18100, Granada, Spain. ${ }^{8}$ Departamento de Microbiología, Facultad de Ciencias, Laboratorio de Parasitología Molecular, Pontificia Universidad Javeriana, Bogotá, Colombia.

Received: 2 December 2011 Accepted: 13 August 2012

Published: 24 August 2012

\section{References}

1. WHO: Chagas disease (American trypanosomiasis) fact sheet (revised in June 2010). Wkly Epidemiol Rec 2010, 85(34):334-336.

2. Schmunis GA, Yadon ZE: Chagas disease: a Latin American health problem becoming a world health problem. Acta Trop 2010 115(1-2):14-21.

3. Field V, Gautret P, Schlagenhauf P, Burchard GD, Caumes E, Jensenius $M$, Castelli F, Gkrania-Klotsas E, Weld L, Lopez-Velez R, et al: Travel and migration associated infectious diseases morbidity in Europe, 2008. BMC Infect Dis 2010, 10:330.

4. Prata A: Clinical and epidemiological aspects of Chagas disease. Lancet Infect Dis 2001, 1(2):92-100.

5. Teixeira AR, Hecht MM, Guimaro MC, Sousa AO, Nitz N: Pathogenesis of chagas' disease: parasite persistence and autoimmunity. Clin Microbiol Rev 2011, 24(3):592-630.

6. Rassi A Jr, Rassi A, Marin-Neto JA: Chagas disease. Lancet 2010, 375(9723):1388-1402.

7. Higuchi Mde L, Benvenuti LA, Martins Reis M, Metzger M: Pathophysiology of the heart in Chagas' disease: current status and new developments. Cardiovasc Res 2003, 60(1):96-107.

8. Martin D, Tarleton R: Generation, specificity, and function of CD8+ T cells in Trypanosoma cruzi infection. Immunol Rev 2004, 201:304-317.

9. Muller U, Sobek V, Balkow S, Holscher C, Mullbacher A, Museteanu C, Mossmann H, Simon MM: Concerted action of perforin and granzymes is critical for the elimination of Trypanosoma cruzi from mouse tissues, but prevention of early host death is in addition dependent on the FasL/Fas pathway. Eur J Immunol 2003, 33(1):70-78.

10. Tarleton RL, Sun J, Zhang L, Postan M: Depletion of T-cell subpopulations results in exacerbation of myocarditis and parasitism in experimental Chagas' disease. Infect Immun 1994, 62(5):1820-1829.

11. Albareda MC, Laucella SA, Alvarez MG, Armenti AH, Bertochi G, Tarleton RL, Postan M: Trypanosoma cruzi modulates the profile of memory CD8+ T cells in chronic Chagas' disease patients. Int Immunol 2006, 18(3):465-471.

12. Shin H, Wherry EJ: CD8 T cell dysfunction during chronic viral infection. Curr Opin Immunol 2007, 19(4):408-415.

13. Leavey JK, Tarleton RL: Cutting edge: dysfunctional CD8+ T cells reside in nonlymphoid tissues during chronic Trypanosoma cruzi infection. J Immunol 2003, 170(5):2264-2268.

14. Tzelepis F, de Alencar BC, Penido ML, Claser C, Machado AV, Bruna-Romero $\mathrm{O}$, Gazzinelli RT, Rodrigues MM: Infection with Trypanosoma cruzi restricts the repertoire of parasite-specific CD8+ T cells leading to immunodominance. J Immunol 2008, 180(3):1737-1748.

15. Alvarez MG, Postan M, Weatherly DB, Albareda MC, Sidney J, Sette A, Olivera C, Armenti AH, Tarleton RL, Laucella SA: HLA Class I-T cell epitopes from trans-sialidase proteins reveal functionally distinct subsets of CD8+ T cells in chronic Chagas disease. PLoS Negl Trop Dis 2008, 2(9):e288.

16. Diez H, Lopez MC, Del Carmen Thomas M, Guzman F, Rosas F, Velazco V Gonzalez JM, Puerta C: Evaluation of IFN-gamma production by CD8 T lymphocytes in response to the K1 peptide from KMP-11 protein in patients infected with Trypanosoma cruzi. Parasit Immunol 2006, 28(3):101-105.

17. Fonseca SG, Moins-Teisserenc $H$, Clave E, lanni B, Nunes VL, Mady C, Iwai LK Sette A, Sidney J, Marin ML, et al: Identification of multiple HLA-A*0201restricted cruzipain and FL-160 CD8+ epitopes recognized by T cells from chronically Trypanosoma cruzi-infected patients. Microb Infect Institut Pasteur 2005, 7(4):688-697.

18. Garcia F, Sepulveda P, Liegeard P, Gregoire J, Hermann E, Lemonnier F, Langlade-Demoyen P. Hontebeyrie M, Lone YC: Identification of HLAA*0201-restricted cytotoxic T-cell epitopes of Trypanosoma cruzi TCP2beta protein in HLA-transgenic mice and patients. Microb Infect Institut Pasteur 2003, 5(5):351-359.
19. Laucella SA, Postan M, Martin D, Hubby Fralish B, Albareda MC, Alvarez MG, Lococo B, Barbieri G, Viotti RJ, Tarleton RL: Frequency of interferongamma -producing $T$ cells specific for Trypanosoma cruzi inversely correlates with disease severity in chronic human Chagas disease. J Infect Dis 2004, 189(5):909-918

20. Martin DL, Weatherly DB, Laucella SA, Cabinian MA, Crim MT, Sullivan S, Heiges M, Craven SH, Rosenberg CS, Collins MH, et al: CD8+ T-Cell responses to Trypanosoma cruzi are highly focused on strain-variant trans-sialidase epitopes. PLoS Pathog 2006, 2(8):e77.

21. Marañón C, Equi A, Carrilero B, Thomas MC, Pinazo MJ, Gascón J, Segovia M, López MC: Identification of HLA-A $* 02: 01$-restricted CTL epitopes in Trypanosoma cruzi heat shock protein-70 recognized by Chagas disease patients. Microb Infect 2011, 13(12-13):1025-1032.

22. Borges M, Da Silva AC, Sereno D, Ouaissi A: Peptide-based analysis of the amino acid sequence important to the immunoregulatory function of Trypanosoma cruzi Tc52 virulence factor. Immunology 2003, 109(1):147-155.

23. Michelin MA, Silva JS, Cunha FQ: Inducible cyclooxygenase released prostaglandin mediates immunosuppression in acute phase of experimental Trypanosoma cruzi infection. Exp Parasitol 2005, 111(2):71-79.

24. Minoprio P, Itohara S, Heusser C, Tonegawa S, Coutinho A: Immunobiology of murine $T$. cruzi infection: the predominance of parasite-nonspecific responses and the activation of TCRI T cells. Immunol Rev 1989, 112:183-207.

25. Poncini CV, Alba Soto CD, Batalla E, Solana ME, Gonzalez Cappa SM: Trypanosoma cruzi induces regulatory dendritic cells in vitro. Infect Immun 2008, 76(6):2633-2641.

26. Padilla AM, Simpson LJ, Tarleton RL: Insufficient TLR activation contributes to the slow development of CD8+ T cell responses in Trypanosoma cruzi infection. J Immunol 2009, 183(2):1245-1252.

27. Krausa P, Brywka M 3rd, Savage D, Hui KM, Bunce M, Ngai JL, Teo DL, Ong YW, Barouch D, Allsop CE, et al: Genetic polymorphism within HLA-A*02: significant allelic variation revealed in different populations. Tissue Antigens 1995, 45(4):223-231.

28. Wherry EJ, Ahmed R: Memory CD8 T-cell differentiation during viral infection. J Virol 2004, 78(11):5535-5545.

29. Appay V, Dunbar PR, Callan M, Klenerman P, Gillespie GM, Papagno L, Ogg GS, King A, Lechner F, Spina CA, et al: Memory CD8+ T cells vary in differentiation phenotype in different persistent virus infections. Nat Med 2002, 8(4):379-385.

30. Sallusto F, Geginat J, Lanzavecchia A: Central memory and effector memory T cell subsets: function, generation, and maintenance. Annu Rev Immunol 2004, 22:745-763.

31. Klenerman $P$, Zinkernagel RM: Original antigenic sin impairs cytotoxic $T$ lymphocyte responses to viruses bearing variant epitopes. Nature 1998, 394(6692):482-485.

32. Britten CM, Janetzki S, Ben-Porat L, Clay TM, Kalos M, Maecker H, Odunsi K, Pride M, Old L, Hoos A, et al: Harmonization guidelines for HLA-peptide multimer assays derived from results of a large scale international proficiency panel of the Cancer Vaccine Consortium. Canc Immunol Immunother 2009, 58(10):1701-1713.

33. Hoji A, Rinaldo CR Jr: Human CD8+ T cells specific for influenza A virus M1 display broad expression of maturation-associated phenotypic markers and chemokine receptors. Immunology 2005, 115(2):239-245.

34. Lasso P, Mesa D, Cuellar A, Guzman F, Bolanos N, Rosas F, Velasco V, Thomas Mdel C, Lopez MC, Gonzalez JM, et al: Frequency of specific CD8+ T cells for a promiscuous epitope derived from Trypanosoma cruzi KMP-11 protein in chagasic patients. Parasite Immunol 2010 32(7):494-502

35. Appay V, Nixon DF, Donahoe SM, Gillespie GM, Dong T, King A, Ogg GS, Spiegel HM, Conlon C, Spina CA, et al: HIV-specific CD8(+) T cells produce antiviral cytokines but are impaired in cytolytic function. J Exp Med 2000, 192(1):63-75.

36. Dauby N, Alonso-Vega C, Suarez E, Flores A, Hermann E, Cordova M, Tellez T, Torrico F, Truyens C, Carlier Y: Maternal infection with Trypanosoma cruzi and congenital Chagas disease induce a trend to a type 1 polarization of infant immune responses to vaccines. PLOS Negl Trop Dis 2009, 3(12):e571.

37. Bern C, Montgomery SP, Herwaldt BL, Rassi A Jr, Marin-Neto JA, Dantas RO, Maguire JH, Acquatella H, Morillo C, Kirchhoff LV, et al: Evaluation and 
treatment of chagas disease in the United States: a systematic review. JAMA 2007, 298(18):2171-2181.

38. Hunt SA: ACC/AHA 2005 guideline update for the diagnosis and management of chronic heart failure in the adult: a report of the American College of Cardiology/American Heart Association Task Force on Practice Guidelines (Writing Committee to Update the 2001 Guidelines for the Evaluation and Management of Heart Failure). J Am Coll Cardiol 2005, 46(6):e1-e82.

39. Bednarek MA, Sauma SY, Gammon MC, Porter G, Tamhankar S, Williamson $A R$, Zweerink HJ: The minimum peptide epitope from the influenza virus matrix protein. Extra and intracellular loading of HLA-A2. J Immunol 1991, 147(12):4047-4053.

40. Chaves F, Calvo JC, Carvajal C, Rivera Z, Ramirez L, Pinto M, Trujillo M, Guzman F, Patarroyo ME: Synthesis, isolation and characterization of Plasmodium falciparum antigenic tetrabranched peptide dendrimers obtained by thiazolidine linkages. J Pept Res Offic J Am Pept Soc 2001, 58(4):307-316.

41. Parham P, Brodsky FM: Partial purification and some properties of BB7.2. A cytotoxic monoclonal antibody with specificity for HLA-A2 and a variant of HLA-A28. Hum Immunol 1981, 3(4):277-299.

42. Bunce M, O'Neill CM, Barnardo MC, Krausa P, Browning MJ, Morris PJ, Welsh KI: Phototyping: comprehensive DNA typing for HLA-A, B, C, DRB1, DRB3, DRB4, DRB5 \& DQB1 by PCR with 144 primer mixes utilizing sequence-specific primers (PCR-SSP). Tissue Antigens 1995, 46(5):355-367.

43. Darrah PA, Patel DT, De Luca PM, Lindsay RW, Davey DF, Flynn BJ, Hoff ST, Andersen P, Reed SG, Morris SL, et al: Multifunctional TH1 cells define a correlate of vaccine-mediated protection against Leishmania major. Nat Med 2007, 13(7):843-850

doi:10.1186/1471-2334-12-198

Cite this article as: Lasso et al: Chagasic patients are able to respond against a viral antigen from influenza virus. BMC Infectious Diseases 2012 12:198.

\section{Submit your next manuscript to BioMed Central and take full advantage of:}

- Convenient online submission

- Thorough peer review

- No space constraints or color figure charges

- Immediate publication on acceptance

- Inclusion in PubMed, CAS, Scopus and Google Scholar

- Research which is freely available for redistribution 